\title{
Effects of nitrogen fertilization on the forest floor carbon balance over the growing season in a boreal pine forest
}

\author{
D. B. Metcalfe ${ }^{1}$, B. Eisele ${ }^{2}$, and N. J. Hasselquist ${ }^{1}$ \\ ${ }^{1}$ Department of Forest Ecology and Management, Swedish University of Agricultural Sciences, 901 83, Umeå, Sweden \\ ${ }^{2}$ Institute of Hydrology, University of Freiburg, Fahnenbergplatz, 79098, Freiburg, Germany
}

Correspondence to: D. B. Metcalfe (dbmetcalfe@gmail.com)

Received: 26 April 2013 - Published in Biogeosciences Discuss.: 26 August 2013

Revised: 7 November 2013 - Accepted: 18 November 2013 - Published: 12 December 2013

\begin{abstract}
Boreal forests play a key role in the global carbon cycle and are facing rapid shifts in nitrogen availability with poorly understood consequences for ecosystem function and global climate change. We quantified the effects of increasing nitrogen availability on carbon fluxes from a relatively understudied component of these forests - the forest floor - at three intervals over the summer growing period in a northern Swedish Scots pine stand. Nitrogen addition altered both the uptake and release of carbon dioxide from the forest floor, but the magnitude and direction of this effect depended on the time during the growing season and the amount of nitrogen added. Specifically, nitrogen addition stimulated net forest floor carbon uptake only in the late growing season. We find evidence for species-specific control of forest floor carbon sink strength, as photosynthesis per unit ground area was positively correlated only with the abundance of the vascular plant Vaccinium myrtillus and no others. Comparison of understorey vegetation photosynthesis and respiration from the study site indicates that understorey vegetation photosynthate was mainly supplying respiratory demands for much of the year. Only in the late season with nitrogen addition did understorey vegetation appear to experience a large surplus of carbon in excess of respiratory requirements. Further work, simultaneously comparing all major biomass and respiratory carbon fluxes in forest floor and tree vegetation, is required to resolve the likely impacts of environmental changes on whole-ecosystem carbon sequestration in boreal forests.
\end{abstract}

\section{Introduction}

Boreal forests store around $25 \%$ of global terrestrial carbon (C) (Gower et al., 2001) and are currently estimated to be a net C sink (Myneni et al., 2001; Pan et al., 2011). These ecosystems are critically constrained across large areas by the availability of N (Tamm, 1991; Vitousek and Howarth, 1991) which is greatly increased across managed forests due to intensive fertilization and, across all systems, via elevated $\mathrm{N}$ inputs from atmospheric deposition (Galloway et al., 2008; Reay et al., 2008). Therefore, increasing $\mathrm{N}$ availability in boreal forests could have major implications for future climate change, both directly by affecting the net flux of carbon dioxide $\left(\mathrm{CO}_{2}\right)$ to the atmosphere, and indirectly by mediating the relative impacts of other climate change agents on boreal vegetation and soils.

Most research to date about the effects of $\mathrm{N}$ on boreal forest $\mathrm{C}$ cycling has focused on trees. By comparison relatively little is known about the effects of fertilization on forest floor $\mathrm{CO}_{2}$ fluxes despite evidence that the forest floor accounts for a large proportion of whole forest photosynthesis and respiration (Goulden and Crill, 1997; Heijmans et al., 2004; Kolari et al., 2006), and exerts a powerful influence over soil nutrient and C cycling (Wardle et al., 1998; Nilsson and Wardle, 2005). The few available $\mathrm{N}$ manipulation studies within boreal and cold temperate forests all suggest that $\mathrm{N}$ addition causes either no change or a slight decline in soil or forest floor $\mathrm{CO}_{2}$ efflux (Gärdenäs, 2000; Olsson et al., 2005; Allison et al., 2008; but see Hasselquist et al., 2012), however, a number of important questions remain. For example, none of these studies partitioned net $\mathrm{CO}_{2}$ efflux from the forest floor into uptake from photosynthesis and release via respiration, 
so it remains unclear to what extent any $\mathrm{N}$-induced shifts in respiration could be offset by concurrent changes in photosynthetic uptake.

A wide range of studies showing inhibited decomposition and soil $\mathrm{CO}_{2}$ efflux following $\mathrm{N}$ addition have formed the empirical foundation for model predictions that global rises in $\mathrm{N}$ deposition will reduce soil $\mathrm{C}$ loss, and hence promote ecosystem C storage (Berg and Matzner, 1997; Ågren et al., 2001; Janssens et al., 2010 and references therein). However, the majority of $\mathrm{N}$ addition experiments (Bond-Lamberty and Thomson, 2010) have fertilized at rates which are several times greater than even the most severe $\mathrm{N}$ deposition scenarios (Lamarque et al., 2005; Galloway et al., 2008; Reay et al., 2008). Some studies have highlighted the potential for non-linear soil $\mathrm{C}$ responses to $\mathrm{N}$ addition rates, (Knorr et al., 2005; Hasselquist et al., 2012). For example, in a boreal Pinus sylvestris L. forest, Hasselquist et al. (2012) found that forest floor $\mathrm{CO}_{2}$ efflux was stimulated by low soil doses of $\mathrm{N}$ but suppressed at higher $\mathrm{N}$ addition rates. The underlying mechanism for this pattern appears to be an increase in the abundance and/or activity of mycorrhizae, with an associated rise in autotrophic respiration under low $\mathrm{N}$ addition, but a strong decrease in the plant-mycorrhizal symbiosis under higher $\mathrm{N}$ loads (Hasselquist et al., 2012) which is consistent with the findings of other studies in the same ecosystem type (Nilsson and Wallander, 2003; Högberg et al., 2010; Vallack et al., 2011). If such non-linear responses are widespread, projections of ecosystem $\mathrm{C}$ sequestration under future $\mathrm{N}$ deposition scenarios may need to be revised.

We measured forest floor net ecosystem exchange of $\mathrm{CO}_{2}$ (NEE), and its components - uptake via photosynthesis (gross primary productivity, GPP) and release through respiration $(R)$ - over a full growing season in the same $\mathrm{N}$ addition experiment described in Hasselquist et al. (2012). For the experiment, $\mathrm{N}$ has been added to the soil since 2006 at two distinct rates in adjacent $P$. sylvestris forest plots to distinguish between the likely impacts of future atmospheric $\mathrm{N}$ deposition versus intensive $\mathrm{N}$ fertilization similar to the rate applied by many scientific studies. Specifically, we asked the following questions.

1. Is forest floor NEE, and its component fluxes, affected in the same way by different $\mathrm{N}$ addition rates?

2. How does $\mathrm{N}$ addition affect the seasonality of forest floor NEE, and its components?

3. Which abiotic (temperature, soil moisture) and biotic (vegetation density, tree proximity) factors explain observed differences in forest floor NEE, and its components?

Finally, as an index of the C status of the understorey plants measured, and how this changes over the growing season and amongst plots, we compare understorey vegetation GPP measured in this study with concurrent data on understorey vegetation respiration $\left(R_{\mathrm{uv}}\right)$ from nearby locations on all plots and measurement periods presented in Hasselquist et al. (2012).

\section{Methods}

\subsection{Study site and experimental design}

The study was located within a homogenous $70 \mathrm{yr}$ old Pinus sylvestris stand at the Rosinedal experimental forest in northern Sweden $\left(64^{\circ} 10^{\prime} \mathrm{N}, 19^{\circ} 45^{\prime} \mathrm{E}\right)$. The site is $\sim 145 \mathrm{~m}$ above sea level, on fine podzolized sand with a thin surface, organic mor layer. Mean annual temperature is $\sim 1^{\circ} \mathrm{C}$, annual rainfall is $520 \mathrm{~mm}$ and the snow-free growing season extends for approximately six months from May to October. A continuous ground layer of vegetation exists, composed of shrubs (Vaccinium myrtillus L., Vaccinium vitis-idaea L.), mosses (Pleurozium schreberi (Bird.) Mitt., Hylocomium splendens (Hedw.) Schimp), and lichens (Cladonia spp). A detailed site summary is presented in Table 1.

At the site, two 15 ha plots have each been subjected to a different fertilization treatment since 2006: addition of $20 \mathrm{~kg} \mathrm{Nha}^{-1} \mathrm{yr}^{-1}$ as $\mathrm{NH}_{4} \mathrm{NO}_{3}$ to replicate a typical rate of atmospheric $\mathrm{N}$ deposition in southern Sweden (low $\mathrm{N}$ plot) (Lamarque et al., 2005), and addition of $100 \mathrm{~kg} \mathrm{~N} \mathrm{ha}^{-1} \mathrm{yr}^{-1}$ to represent a fertilization intensity typical of many scientific fertilization experiments (high N plot) (Bond-Lamberty and Thomson, 2010; Hasselquist et al., 2012). Fertilizer is applied in the form of soluble pellets once a year in late June. Adjacent to these plots is a matching 15 ha area of unfertilized forest which acts as an experimental control. While these $\mathrm{N}$ treatments were not replicated (Hurlbert, 1984) due to logistical and financial constraints, they provide insights into ecosystem processes at a spatial scale which would be impossible to achieve with smaller scale, more easily replicated manipulations (Carpenter, 1996, 1998; Sullivan, 1997; Osmond et al., 2004). To assess plot similarities prior to fertilization, 15 trees were harvested prior to fertilization in 2006, and a further 6 trees in each $\mathrm{N}$ treatment were harvested in 2011 (27 harvested trees total) to develop allometric equations relating stem diameter to volume for each plot. Wood cores were taken to calculate specific wood density for each plot, to convert wood volume to biomass. Scanned wood disks (at $1.3 \mathrm{~m}$ above the ground) from trees harvested in 2011 were used to calculate stem ring growth expansion from 2004 onwards, and the allometric equations were applied to these values to calculate incremental biomass increase. Results show that stem production on the fertilized plots was similar to the control prior to fertilization, but accelerated relative to the control after fertilization (Table 1). Given that stem biomass and production are important integrators of multiple forest processes (Gamfeldt et al., 2013), we interpret this as reasonable evidence that tree and understorey vegeta- 
Table 1. Summary of plot characteristics in 2011. Values represent mean \pm SE $(n=17)$. Soil moisture and temperature values represent means across the growing season (June-August). *From Hasselquist et al. (2012). Tree stem growth values in brackets represent means for the three years prior to fertilization.

\begin{tabular}{lrrr}
\hline & Control & Low & High \\
\hline Tree stem growth $\left(\mathrm{g} \mathrm{m}^{-2} \mathrm{yr}^{-1}\right)$ & $280^{*}$ & $340^{*}(280)$ & $500^{*}(298)$ \\
V. myrtillus density $\left(\mathrm{stems} \mathrm{m}^{-2}\right)$ & $76 \pm 8$ & $75 \pm 12$ & $79 \pm 11$ \\
V. vitis-idaea density $\left(\mathrm{stems} \mathrm{m}{ }^{-2}\right)$ & $151 \pm 12$ & $205 \pm 11$ & $208 \pm 14$ \\
Organic layer depth $(\mathrm{cm})$ & $10.0 \pm 0.8$ & $9.4 \pm 0.6$ & $9.3 \pm 0.7$ \\
Organic layer C $: \mathrm{N}$ ratio & $39.2 \pm 1.3^{*}$ & $40.7 \pm 1.3^{*}$ & $40.2 \pm 1.3^{*}$ \\
Soil moisture $(\%)$ & $10.3 \pm 0.4$ & $10.5 \pm 0.5$ & $10.2 \pm 0.4$ \\
Soil temperature $\left({ }^{\circ} \mathrm{C}\right)$ & $11.1 \pm 0.4$ & $11.7 \pm 0.4$ & $10.8 \pm 0.4$
\end{tabular}

tion structure and composition were broadly similar across plots prior to fertilization.

\subsection{Sampling and data analyses}

Forest floor $\mathrm{CO}_{2}$ exchange was surveyed on all three plots over a two-week time window in June (9-16th), July (1929th) and August (19-25th) of 2011 to capture variation over the active growing period for understorey vegetation in boreal forests. In each plot, 17 locations were selected for forest floor $\mathrm{CO}_{2}$ flux measurements. Prior to measurements, $40 \mathrm{~cm} \times 40 \mathrm{~cm}$ metal bases were inserted $\sim 2 \mathrm{~cm}$ into the soil surface, taking care to minimize disturbance to surrounding vegetation and roots. After allowing a minimum of two days for equilibration, forest floor $\mathrm{CO}_{2}$ fluxes were recorded by sealing a $40 \mathrm{~cm}$ high transparent plastic chamber to the chamber base, and recording the linear accumulation of $\mathrm{CO}_{2}$ within the chamber over two minutes using an infrared gas analyser or IRGA (EGM-4, PP Systems, PP Systems, Hitchin, UK). A light sensor was placed inside the chamber to continuously record the amount of photosynthetically active radiation (PAR, $\mu \mathrm{mol} \mathrm{m} \mathrm{m}^{-2} \mathrm{~s}^{-1}$ ) received by the vegetation within the chamber during $\mathrm{CO}_{2}$ measurements. The air inside the chamber was thoroughly mixed during measurements with a fan. The measurement duration was sufficiently short to minimize changes in air temperature and humidity within the chamber. At each location, $\mathrm{CO}_{2}$ fluxes were recorded eight times, five records under different PAR levels and three replicate measurements in complete darkness. Mesh covers were used to reduce PAR within the chamber, while a completely opaque cover was used to reduce PAR to zero. The flux measured represents net ecosystem exchange of $\mathrm{CO}_{2}$ from the understorey vegetation, soil and tree roots (NEE, $\mathrm{g} \mathrm{CO}_{2} \mathrm{~m}^{-2} \mathrm{~h}^{-1}$ ):

$\mathrm{NEE}=R-\mathrm{GPP}$,

where GPP is understorey vegetation gross primary productivity $\left(\mathrm{g} \mathrm{CO}_{2} \mathrm{~m}^{-2} \mathrm{~h}^{-1}\right.$ ), and $R$ is forest floor respiration of $\mathrm{CO}_{2}\left(\mathrm{~g} \mathrm{CO}_{2} \mathrm{~m}^{-2} \mathrm{~h}^{-1}\right)$. A negative value of NEE indicates that GPP is greater than $R$ and therefore that the location at that time is sequestering $\mathrm{CO}_{2}$, whereas a positive value of
NEE indicates that $R$ is dominating and so the location is a net source of $\mathrm{CO}_{2}$. Under complete darkness, photosynthesis does not occur so the $\mathrm{CO}_{2}$ flux represents $R$. $\mathrm{CO}_{2}$ measurements were performed between 09:00 and 16:00 LT (local time) on the sampling days. Forest floor GPP may then be estimated for each location by adding mean $R$ to NEE at a particular level of PAR. For each location and time period, we fit a three-parameter decay model to the relationship between PAR and measured forest floor NEE by minimizing the root mean square error between observed and predicted NEE values using Excel solver (Shaver et al., 2013):

$y=a+b \times \exp ^{-c \times p}$,

where $y$ represents modelled NEE, $a, b$ and $c$ represent the three fitted curve parameters and $p$ refers to measured PAR. Thus, in total, 153 unique curve parameter sets were derived ( 51 locations $\times 3$ time periods), and used to predict NEE and GPP at a standardized PAR value of $600 \mu \mathrm{mol} \mathrm{m} \mathrm{m}^{-2} \mathrm{~s}^{-1}$ for each location and time period. The parameter sets were used to enable direct comparison of light-dependant $\mathrm{CO}_{2}$ fluxes amongst locations and time periods, and were not applied beyond the immediate conditions under which they were fit.

After $\mathrm{CO}_{2}$ flux measurement, a range of abiotic and biotic plot variables were measured at each location. Surface (0$10 \mathrm{~cm}$ soil depth) soil moisture and temperature was recorded instantaneously with probes (Hydrosense moisture probe, Campbell Scientific Instruments, Logan, Utah; Model E514 temperature probe, Mingle Instrument, Willich, Germany) at four replicate points within the metal base at each location. The depth of the organic layer was visually estimated, and the number of $V$. myrtillus and $V$. vitis-idaea stems was counted as a estimate of vegetative density. To measure the temporal development of foliar density over the season, photographs were taken of each $\mathrm{CO}_{2}$ measurement location with a digital camera (Coolpix S800c, Nikon Corporation, Tokyo, Japan), and the images were analysed with software (ImageJ, NIH, USA) to calculate the raw digital numbers in the red $\left(R_{\mathrm{dn}}\right)$, green $\left(G_{\mathrm{dn}}\right)$ and blue $\left(B_{\mathrm{dn}}\right)$ channels. The following equation was used to compute a greenness index $\left(I_{\mathrm{g}}\right)$ from these 
values (Richardson et al. 2007):

$I_{\mathrm{g}}=G_{\mathrm{dn}} /\left(R_{\mathrm{dn}}+G_{\mathrm{dn}}+B_{\mathrm{dn}}\right)$.

Finally, to investigate and, if necessary, control for the effects of tree proximity on root biomass and respiration, and hence forest floor $\mathrm{CO}_{2}$ efflux, we measured the diameter of all trees within a $3.5 \mathrm{~m}$ radius of each location and computed a tree proximity index $(T)$ :

$T=\sum s \times(1 / d)$

where $s$ represents tree size as diameter at $1.3 \mathrm{~m}(\mathrm{~cm})$ and $d$ represents tree distance from the $\mathrm{CO}_{2}$ flux measurement location $(\mathrm{cm})$. We conducted a non-parametric Spearman's rank test to assess correlations amongst the $\mathrm{CO}_{2}$ fluxes measured and a range of abiotic and biotic variables recorded at each location. To assess the causes of spatial variation in $\mathrm{CO}_{2}$ fluxes amongst locations, correlations were run separately for each sampling period. To assess temporal variation in $\mathrm{CO}_{2}$ fluxes, we first controlled for spatial variation amongst points by dividing values for each location by the mean across all sampling periods for the same location. From this standardized data, we then calculated the slope of change in $\mathrm{CO}_{2}$ fluxes, temperature, moisture and vegetation greenness for all locations across the three time periods, then ran correlation analyses on these slopes. All statistical analyses were conducted with SPSS statistics software (IBM SPSS 19.0 for Windows, IBM Corporation, Armonk, USA).

For comparison with understorey vegetation GPP estimates in this study, we used $R_{\mathrm{uv}}$ estimates from another study conducted on the same forest plots within a week before and after our own $\mathrm{CO}_{2}$ measurements (Hasselquist et al., 2012). Details of $R_{\mathrm{uv}}$ measurement and experimental design are presented in Hasselquist et al. (2012), and summarized here. $R_{\mathrm{uv}}$ was recorded at six blocks per plot, blocks were $<20 \mathrm{~m}$ from the 17 locations per plot sampled in this study. At each block, two collars ( $25 \mathrm{~cm}$ diameter) were inserted to $25 \mathrm{~cm}$ soil depth, thereby removing most contributions from tree roots (since the majority of fine pine roots at the site occur within the surface $20 \mathrm{~cm}$ soil layer, data not shown). Understorey vegetation was left intact in one of the collars (C3), while in the other, above-ground plant parts were removed (C2). These collars were installed ten months prior to the first $\mathrm{CO}_{2}$ flux measurement to minimize biases from plant removal and soil disturbance. $\mathrm{CO}_{2}$ efflux was recorded from all collars on every plot regularly over the growing season of 2011 by sealing the collar with an opaque top and recording $\mathrm{CO}_{2}$ accumulation within the collar headspace with a $\mathrm{CO}_{2}$ sensor (CARBOCAP model GMP 343, Vaisala, Finland). $R_{\mathrm{uv}}\left(\mathrm{g} \mathrm{CO}_{2} \mathrm{~m}^{-2} \mathrm{~h}^{-1}\right)$ was calculated by subtracting $\mathrm{CO}_{2}$ efflux in $\mathrm{C} 3$ from $\mathrm{CO}_{2}$ efflux in $\mathrm{C} 2$ for each block and time period.

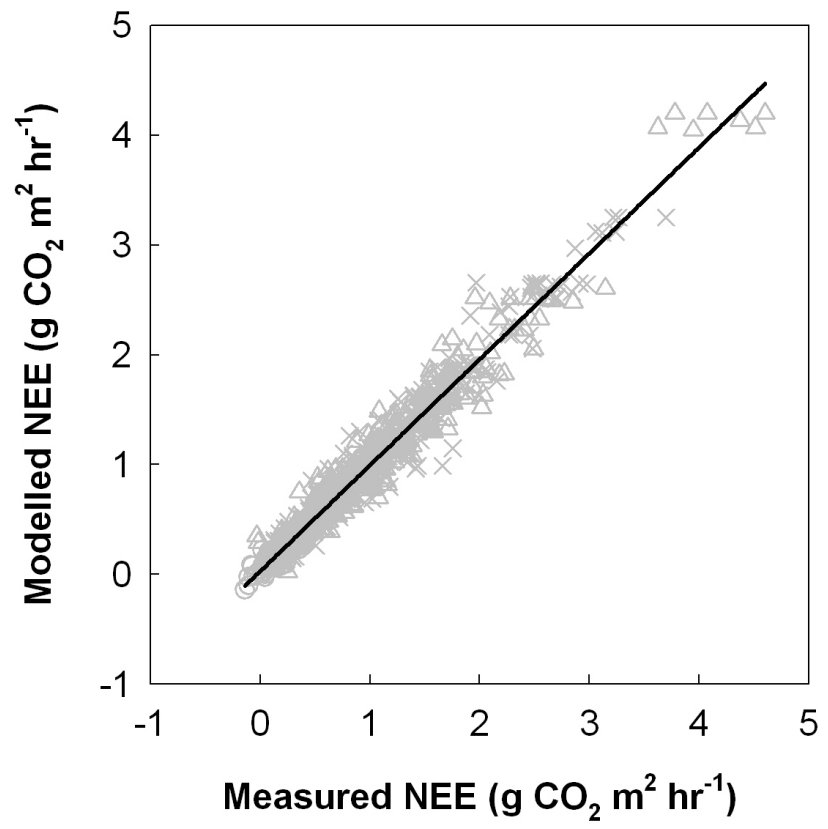

Fig. 1. Measured versus modelled forest floor NEE. Modelled NEE was estimated from a three parameter decay model fit to measurements. Positive values denote net release of $\mathrm{CO}_{2}$ from the forest floor into the atmosphere. Circles, triangles and crosses represent measurements in the early, middle and late growing season respectively. The line is a linear regression fit through all the data $\left(y=0.9652 x+0.0268, R^{2}=0.95\right.$, root mean square error $\left.=0.13\right)$.

\section{Results}

Fitted curve parameter sets for each location and time period were used to predict forest floor NEE and GPP at $600 \mu \mathrm{mol} \mathrm{m}{ }^{-2} \mathrm{~s}^{-1}$ for the same location and period. Across all measurement locations and time periods $(n=153)$, there was a close agreement between measured and modelled NEE (Fig. 1).

$\mathrm{N}$ addition altered both forest floor $R$ and GPP but the magnitude and direction of the effect depended strongly on timing during the season and, to a lesser extent, the amount of $\mathrm{N}$ added (Fig. 2). Across all measurements, forest floor $R$ increased over the growing season, but the pattern of this increase was significantly modified by $\mathrm{N}$ treatment (Fig. 2). In the early season, $R$ was generally low across all plots, but was only stimulated on the low $\mathrm{N}$ treatment relative to the control. In contrast, from July onwards $R$ was suppressed on the low $\mathrm{N}$ treatment, and to an even greater extent, on the high $\mathrm{N}$ treatment compared to the control. By comparison with forest floor $R$, GPP was generally lower in magnitude, more variable and showed no clear $\mathrm{N}$ treatment effect (Fig. 2). Hence, seasonal and treatment patterns of NEE were mainly driven by shifts in forest floor $R$. There was no clear and consistent overall $\mathrm{N}$ treatment effect on NEE across all measurement campaigns. However, considering 

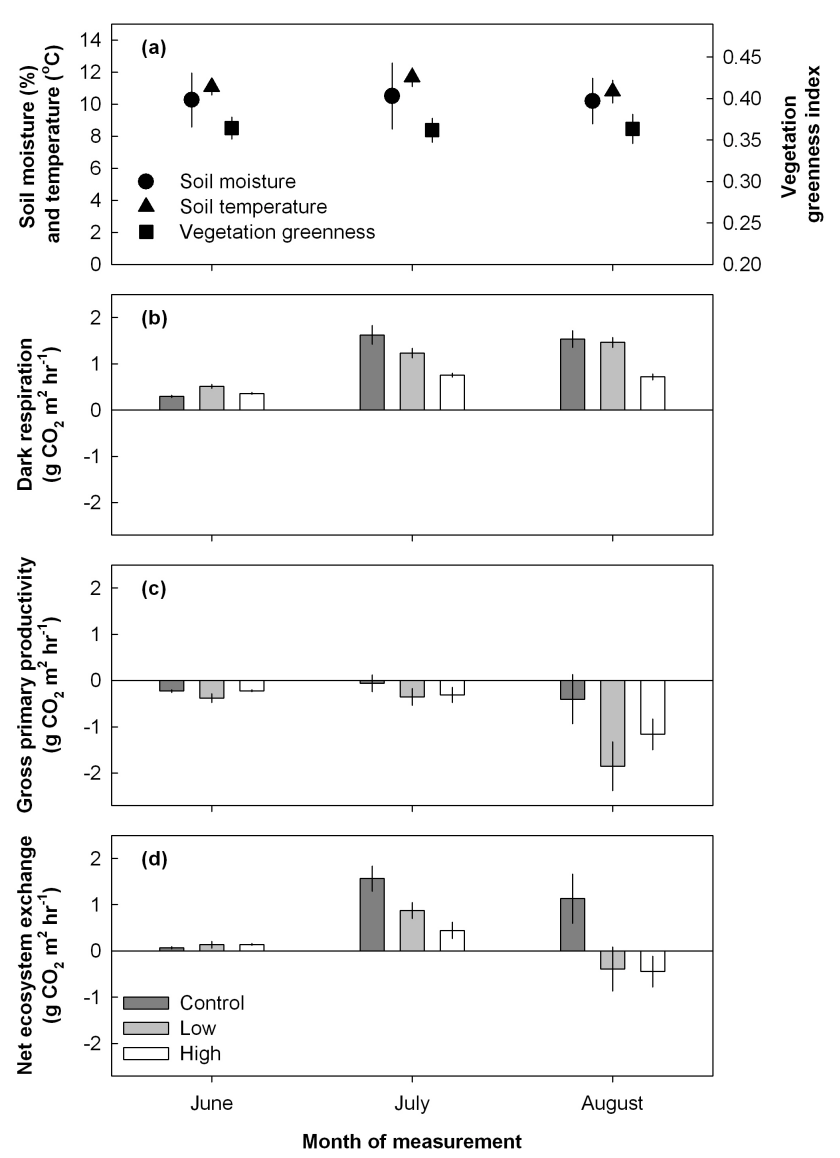

Fig. 2. Changes in soil and vegetation properties (a), forest floor fluxes of $\mathrm{CO}_{2}$ from $R(\mathbf{b})$, GPP (c) and NEE (d) in plots with different $\mathrm{N}$ addition rates over the growing season. Values of GPP and $\mathrm{NEE}$ are standardized to a light intensity of $600 \mu \mathrm{mol} \mathrm{m} \mathrm{m}^{-2} \mathrm{~s}^{-1}$. Positive values denote net release of $\mathrm{CO}_{2}$ from the forest floor into the atmosphere, error bars represent SE $(n=17)$.

each measurement period individually, some plot differences were apparent (Fig. 2). The high $\mathrm{N}$ treatment was a smaller net $\mathrm{C}$ source than the control in July, mainly due to plot differences in forest floor $R$ rather than GPP. In addition, both $\mathrm{N}$ treatments were substantially greater net $\mathrm{C}$ sinks than the control in the later part of the growing season (August).

Forest floor $R$ and GPP displayed distinct seasonal patterns which had an important impact on NEE (Fig. 2). Forest floor $R$ reached maximal levels from July onwards and was closely correlated with temporal variation in soil temperature (Table 2). In contrast, GPP peaked only later in August and was not significantly related to seasonal change in soil temperature, soil moisture or understorey vegetation greenness index (Table 2). This temporal lag between $R$ and GPP meant that the forest floor on all plots had a greater tendency towards being a large net $\mathrm{C}$ source in the middle of the growing season (Fig. 2). By contrast, in the early and late portions of the growing season, forest floor NEE was more neutral because $R$ and GPP approximately offset each other (Fig. 2).

No significant correlation was found between tree proximity and any of the $\mathrm{CO}_{2}$ fluxes measured (Table 2), so we conclude that it was not a major source of confounding variation in our analyses. Within each sampling period, spatial variation in forest floor $\mathrm{CO}_{2}$ fluxes was most often significantly associated with indices of vegetation density, commonly $V$. myrtillus abundance and greenness index, and soil temperature (Table 2). Despite the significance of correlations, the portion of variance in forest floor $\mathrm{CO}_{2}$ fluxes explained by the variables measured was typically very low $(<10 \%)$, with the exceptions of the associations between $V$. myrtillus abundance, $R$ (in June) and GPP (in July), and the link between temperature and $R$ in July (Table 2). In contrast with $V$. myrtillus, spatial variation in $V$. vitis-idaea density was not correlated with any $\mathrm{CO}_{2}$ fluxes (Table 2), providing evidence for species-specific effects on forest floor $\mathrm{CO}_{2}$ uptake. Of the observed seasonal variation in forest floor $\mathrm{CO}_{2}$ fluxes, only $R$ was significantly correlated with temporal change in any of the abiotic and biotic variables measured (with soil temperature, Table 2).

As a rough indicator of the internal $\mathrm{C}$ balance of understorey plants, we compared measured understorey vegetation GPP in each plot and time period during the growing season with estimates of understorey vegetation respiration $\left(R_{\mathrm{uv}}\right)$ measured over the same periods on the same plots, and presented in Hasselquist et al. (2012). At a light intensity of $600 \mu \mathrm{mol} \mathrm{m} \mathrm{m}^{-1}$, which is generally higher than that predominating at the ground level at the study site, understorey vegetation uptake of $\mathrm{CO}_{2}$ via GPP only just covered estimated plant respiratory demand on all plots in the early and middle growing season (Fig. 3). By August, however, understorey vegetation in the $\mathrm{N}$ addition plots were operating a large $C$ surplus at $600 \mu \mathrm{mol} \mathrm{m} \mathrm{s}^{-1}$, acquiring $\sim 50$ and 30 times more $\mathrm{C}$ than was required for plant respiration on the low and high $\mathrm{N}$ plots, respectively (Fig. 3). In contrast, at the same time in the late growing season, the $\mathrm{C}$ surplus at $600 \mu \mathrm{mol} \mathrm{m} \mathrm{s}^{2} \mathrm{~s}^{-1}$ in control plot vegetation was much lower and largely unchanged from early growing season levels (Fig. 3).

\section{Discussion}

Boreal forests are currently estimated to be a net $\mathrm{C}$ sink (Myneni et al., 2001; Pan et al., 2011), but the contribution of the forest floor to this sink is currently poorly understood. One striking pattern emerging from this study was that the forest floor was generally a very weak net sink for $\mathrm{CO}_{2}$ even over the peak growing season (Fig. 2). Spatial variation in GPP was often linked to variation in indices of vegetation density (Table 2), but the strong seasonal variation in GPP (Fig. 2) appeared to occur independently of shifts in vegetation greenness (Table 2) suggesting that it was driven 
Table 2. Results of a Spearman's rank correlation between forest floor $\mathrm{CO}_{2}$ fluxes and a range of abiotic and biotic variables. Analyses across all seasons are run on the entire data set from the slopes of temporal change in variables transformed to control for spatial variation amongst locations. Significant correlations $(\leq 0.05)$ are highlighted in bold. CC refers to the correlation coefficient, negative and positive CC values denote a negative and positive correlation respectively.

\begin{tabular}{|c|c|c|c|c|c|c|c|c|c|}
\hline & \multicolumn{3}{|c|}{$R$} & \multicolumn{3}{|c|}{ GPP } & \multicolumn{3}{|c|}{ NEE } \\
\hline & $R^{2}$ & $\mathrm{CC}$ & $\mathrm{P}$ & $R^{2}$ & $\mathrm{CC}$ & $\mathrm{P}$ & $R^{2}$ & $\mathrm{CC}$ & $\mathrm{P}$ \\
\hline \multicolumn{10}{|l|}{ June } \\
\hline Tree proximity index & $<0.01$ & -0.13 & 0.36 & 0.02 & 0.06 & 0.70 & 0.03 & -0.22 & 0.13 \\
\hline Organic layer depth $(\mathrm{cm})$ & 0.02 & 0.11 & 0.44 & 0.08 & 0.35 & 0.01 & 0.06 & -0.21 & 0.14 \\
\hline V. myrtillus density (stems $\mathrm{m}^{-2}$ ) & 0.20 & 0.31 & 0.03 & 0.09 & 0.51 & $<0.001$ & $<0.01$ & -0.08 & 0.56 \\
\hline V. vitis-idaea density $\left(\right.$ stems $\left.\mathrm{m}^{-2}\right)$ & $<0.01$ & -0.10 & 0.50 & $<0.01$ & -0.20 & 0.15 & $<0.01$ & 0.07 & 0.61 \\
\hline Vegetation density (stems $\mathrm{m}^{-2}$ ) & 0.12 & 0.23 & 0.11 & 0.05 & 0.24 & 0.09 & $<0.01$ & 0.05 & 0.73 \\
\hline Greenness index & 0.07 & 0.18 & 0.22 & 0.05 & 0.50 & $<0.001$ & 0.01 & -0.27 & 0.06 \\
\hline Soil moisture $(\%)$ & 0.01 & -0.11 & 0.43 & $<0.01$ & 0.10 & 0.48 & 0.01 & -0.07 & 0.64 \\
\hline Soil temperature $\left({ }^{\circ} \mathrm{C}\right)$ & 0.06 & 0.20 & 0.16 & $<0.01$ & -0.24 & 0.10 & $\mathbf{0 . 0 3}$ & $\mathbf{0 . 3 3}$ & 0.02 \\
\hline \multicolumn{10}{|l|}{ July } \\
\hline Tree proximity index & 0.03 & 0.18 & 0.20 & $<0.01$ & 0.05 & 0.71 & 0.01 & -0.03 & 0.82 \\
\hline Organic layer depth $(\mathrm{cm})$ & $<0.01$ & 0.12 & 0.42 & 0.05 & -0.15 & 0.29 & 0.03 & 0.16 & 0.26 \\
\hline V. myrtillus density (stems $\mathrm{m}^{-2}$ ) & $<0.01$ & 0.20 & 0.16 & 0.13 & $\mathbf{0 . 3 0}$ & 0.03 & 0.05 & -0.13 & 0.33 \\
\hline V. vitis-idaea density (stems $\mathrm{m}^{-2}$ ) & 0.03 & -0.19 & 0.18 & 0.01 & -0.01 & 0.36 & $<0.01$ & -0.02 & 0.91 \\
\hline Vegetation density $\left(\right.$ stems $\mathrm{m}^{-2}$ ) & 0.02 & -0.09 & 0.53 & 0.05 & 0.19 & 0.18 & 0.06 & -0.22 & 0.12 \\
\hline Greenness index & $<0.01$ & 0.29 & 0.04 & 0.01 & 0.19 & 0.19 & $<0.01$ & 0.06 & 0.70 \\
\hline Soil moisture (\%) & $\mathbf{0 . 0 2}$ & 0.31 & $\mathbf{0 . 0 3}$ & $<0.01$ & 0.17 & 0.23 & 0.01 & 0.04 & 0.77 \\
\hline Soil temperature $\left({ }^{\circ} \mathrm{C}\right)$ & 0.17 & 0.55 & $<0.001$ & 0.01 & 0.02 & 0.88 & 0.02 & 0.32 & 0.02 \\
\hline \multicolumn{10}{|l|}{ August } \\
\hline Tree proximity index & 0.01 & 0.10 & 0.49 & $<0.01$ & $<0.01$ & 0.99 & $<0.01$ & 0.05 & 0.72 \\
\hline Organic layer depth $(\mathrm{cm})$ & $<0.01$ & 0.04 & 0.78 & 0.05 & 0.19 & 0.18 & 0.04 & -0.26 & 0.06 \\
\hline V. myrtillus density (stems $\mathrm{m}^{-2}$ ) & 0.01 & -0.07 & 0.64 & 0.08 & 0.13 & 0.35 & 0.10 & -0.16 & 0.25 \\
\hline V. vitis-idaea density (stems $\mathrm{m}^{-2}$ ) & $<0.01$ & -0.03 & 0.84 & $<0.01$ & 0.18 & 0.20 & $<0.01$ & -0.20 & 0.17 \\
\hline Vegetation density (stems $\mathrm{m}^{-2}$ ) & 0.01 & -0.16 & 0.27 & 0.05 & 0.27 & 0.06 & 0.06 & -0.30 & 0.03 \\
\hline Greenness index & 0.02 & 0.14 & 0.31 & 0.08 & 0.30 & 0.03 & 0.08 & -0.26 & 0.06 \\
\hline Soil moisture (\%) & 0.01 & -0.03 & 0.84 & 0.02 & -0.14 & 0.33 & 0.02 & 0.19 & 0.19 \\
\hline Soil temperature $\left({ }^{\circ} \mathrm{C}\right)$ & $<0.01$ & 0.70 & $<0.001$ & 0.02 & 0.11 & 0.45 & 0.02 & 0.10 & 0.49 \\
\hline \multicolumn{10}{|l|}{ All seasons } \\
\hline Greenness index & $<0.01$ & 0.06 & 0.67 & $<0.01$ & 0.05 & 0.71 & $<0.01$ & -0.18 & 0.21 \\
\hline Soil moisture (\%) & 0.03 & 0.14 & 0.33 & 0.02 & 0.02 & 0.91 & $<0.01$ & -0.08 & 0.59 \\
\hline Soil temperature $\left({ }^{\circ} \mathrm{C}\right)$ & 0.09 & 0.30 & 0.03 & $<0.01$ & 0.20 & 0.17 & $<0.01$ & 0.10 & 0.50 \\
\hline
\end{tabular}

instead by seasonal changes in leaf-level photosynthesis or respiration rates. Though the lack of clear change in vegetation greenness (Fig. 1a) suggested that our sampling occurred after the main period of understorey vegetation leaf flush. Understorey vegetation $\mathrm{CO}_{2}$ uptake at a light intensity of $600 \mu \mathrm{mol} \mathrm{m} \mathrm{m}^{-2} \mathrm{~s}^{-1}$ (equivalent to full sun with a typical canopy light interception for this type of forest of $\sim 80 \%$, Mencuccini and Grace, 1996) could barely cover respiratory demand for much of the year (Fig. 3). It is possible that these plants may derive a disproportionate amount of photosynthate from short-lived sunflecks (Lieffers et al., 1999). Indeed, we found little sign of GPP saturating at high light levels, contrary to previous reports from similar systems (Kolari et al., 2006; Whitehead and Gower, 2001), indicating that understorey plants at the site may have high photosynthetic capacity to exploit ephemeral bright periods. Nevertheless, the fact that full sun conditions are rare, and that light intensity drops at night even at these high latitudes in summer, suggests that for much of the year little assimilated $\mathrm{C}$ remains for other functions (e.g.: growth, herbivore defense and reproduction) in understorey plant species at this site after basic metabolic demands have been satisfied. This appears incongruent with widely cited reports that understorey NPP is over half of above-ground tree NPP in a chronosequence of boreal forest (Wardle et al., 2003; Nilsson and Wardle, 2005) but total above-ground NPP in these systems is very low, at less 


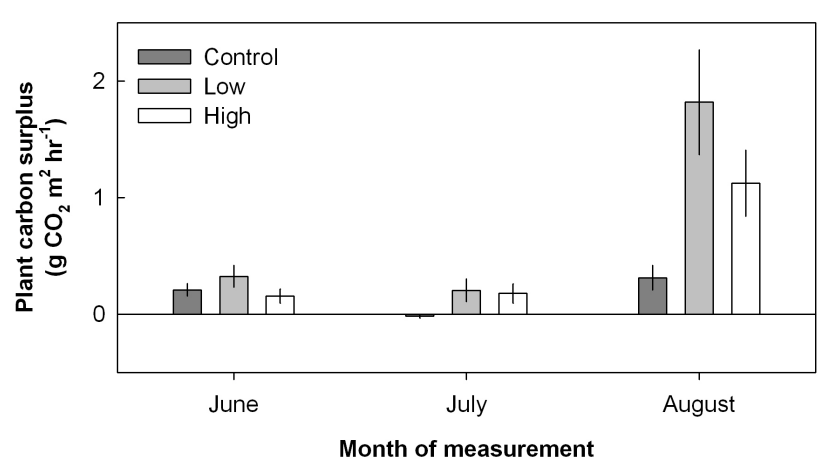

Fig. 3. Plant carbon surplus potential - calculated as GPP at a light intensity of $600 \mu \mathrm{mol} \mathrm{m}{ }^{-2} \mathrm{~s}^{-1}$ minus $R_{\mathrm{uv}}-$ in plots with different $\mathrm{N}$ addition rates over the growing season. Error bars represent $\mathrm{SE}(n=$ 17 and 2 for GPP and $R_{\mathrm{uv}}$ respectively). $R_{\mathrm{uv}}$ values were derived from Hasselquist et al. (2012) from locations $<20 \mathrm{~m}$ from the points measured in this study in all plots and measurement periods.

than $150 \mathrm{~g} \mathrm{C} \mathrm{m}^{-2} \mathrm{yr}^{-1}$ compared to $232 \mathrm{~g} \mathrm{C} \mathrm{m}^{-2} \mathrm{yr}^{-1}$ from a pan-boreal synthesis (Gower et al., 2001). Thus, in absolute terms, understorey NPP along the chronosequence sites is still low ( $<45 \mathrm{~g} \mathrm{C} \mathrm{m}^{-2} \mathrm{yr}^{-1}$, Nilsson and Wardle, 2005), and likely to be lower still in more dense forests where carbon uptake in the understorey is more strongly light limited. Analyses of understorey $\mathrm{C}$ allocation in boreal forests are still limited by the paucity of available data, but a preliminary comparison supports this hypothesis: taking published values for boreal forest understorey vegetation GPP and NPP of $\sim 130 \mathrm{~g} \mathrm{C} \mathrm{m}^{-2} \mathrm{yr}^{-1}$ and $\sim 30 \mathrm{~g} \mathrm{C} \mathrm{m}^{-2} \mathrm{yr}^{-1}$ respectively (Gower et al., 2001; Kolari et al., 2006), the portion of understorey photosynthate allocated to growth is extremely low ( $23 \%$ ) compared to mean values for boreal trees of $40-50 \%$ (Vicca et al., 2012). Indeed, clonal plant growth and efficient nutrient resorption are relatively common strategies amongst boreal understorey plants, and are thought to be an adaptive trait to increase resource use efficiency (Eckstein et al., 1999; Svensson et al., 2009). This does not necessarily mean that the contribution of boreal understorey plants to ecosystem $\mathrm{C}$ storage is insignificant, since many such plants turnover biomass rapidly and produce recalcitrant organic litter that retards soil microbial activity thereby promoting soil C sequestration (Chapin, 1983; Wardle et al., 1998; Nilsson and Wardle, 1999; Wardle and Zackrisson, 2005).

This study shows that $\mathrm{N}$ fertilization effects on forest floor $\mathrm{CO}_{2}$ fluxes were dependent firstly on the time during the growing season and secondly on the amount of $\mathrm{N}$ added (Fig. 2). In the early growing season, forest floor $R$ responded in a similar way to $\mathrm{N}$ addition as that noted by Hasselquist et al. (2012) from the same study site: with greater levels of $\mathrm{CO}_{2}$ released as $R$ under low levels of $\mathrm{N}$ addition compared to both the control and high $\mathrm{N}$ plots. However, later in the season we recorded a different response, more in line with the consensus view (Janssens et al., 2010, and references therein) - showing successively lower forest floor $R$ on the low and high plots relative to the control, pointing to $\mathrm{N}$-induced suppression of organic matter decomposition and/or microbial activity (Fig. 2). The reasons for the differences between the current study and Hasselquist et al. (2012) may be partly due to differences in the timing of measurements. The stimulation of autotrophic respiration, and hence total $R$, on the low $\mathrm{N}$ treatment was maximal in late August and September, after the period of sampling in this study. However, we note that our results still highlight the risks of inferring likely effects of atmospheric $\mathrm{N}$ deposition from fertilization experiments which apply $\mathrm{N}$ at much higher rates, since we do not observe a monotonic linear response to the fourfold increase in $\mathrm{N}$ addition from the low to high plot. Instead, the effects of $\mathrm{N}$ on forest floor $\mathrm{CO}_{2}$ fluxes tended to saturate with increasing rates of $\mathrm{N}$ addition.

$\mathrm{N}$ availability will also have large impacts on the composition and diversity of understorey plant communities (Bobbink et al., 2010). In this study, we find evidence for speciesspecific effects on forest floor $\mathrm{CO}_{2}$ fluxes, since GPP was significantly positively correlated with the abundance of $V$. myrtillus but not related to the amount of $V$. vitis-idaea (Table 2). Important impacts of fertilization on forest floor $\mathrm{CO}_{2}$ fluxes, beyond the short-term increases in leaf $\mathrm{N}$ and soil microbial activity, could therefore operate over longer timescales by shifting the relative abundance of species with different capacities to take up and store $\mathrm{C}$ in plant tissue and soil. Although we have not yet observed a substantial shift in V. myrtillus abundance at the study site (Table 1), longer-term forest fertilization experiments have demonstrated substantial declines in $V$. myrtillus abundance, even up to nine years after nitrogen addition ceased (Strengbom et al., 2001; Nordin et al., 2005; Strengbom and Nordin, 2008). Our results suggest that such a plant community shift could reduce understorey GPP, and therefore partly offset the beneficial effects of forest fertilization in terms of enhanced tree C uptake (De Vries et al., 2006). Integration of such longer-term, indirect effects of environmental changes on ecosystem $C$ storage via shifts in plant community composition are poorly constrained in global models compared to the direct impacts of abiotic factors such as temperature and moisture (Ostle et al., 2009; Metcalfe et al., 2011). Therefore, further work linking together community ecology and $\mathrm{C}$ cycling are required to improve model predictions of forest $\mathrm{C}$ sequestration in a changing world.

\section{Conclusions}

To improve understanding of $\mathrm{C}$ and $\mathrm{N}$ interactions in boreal forests, we studied seasonal $\mathrm{C}$ fluxes from an important but often overlooked component of forests - the forest floor in a large-scale forest $\mathrm{N}$ manipulation experiment. Overall, we found that $\mathrm{N}$ addition tends to increase the likelihood that the forest floor will be a net $\mathrm{C}$ sink, but that this is strongly 
dependent upon the timing during the growing season and, to a lesser extent, the amount of $\mathrm{N}$ added. Whether this additional $\mathrm{C}$ taken up under fertilized conditions will contribute to long-term $\mathrm{C}$ sequestration is, however, unclear because most assimilated $\mathrm{C}$ is apparently directly respired. This tentative conclusion would be reinforced by simultaneous measurements of biomass growth and respiratory $\mathrm{C}$ fluxes in understorey vegetation, but is consistent with available information about the carbon allocation and life history strategies of understorey plants.

Acknowledgements. This work was supported by a grant from the The Royal Swedish Academy of Agriculture and Forestry (H11-0149). We are grateful to P. Högberg and S. Linder for comments on the grant proposal and for access to the study site.

Edited by: E. Veldkamp

\section{References}

Ågren, G. I., Bosatta, E., and Magill, A. H.: Combining theory and experiment to understand effects of inorganic nitrogen on litter decomposition, Oecologia, 128, 94-98, 2001.

Allison, S. D., Czimzik, C. I., and Treseder, K. K.: Microbial activity and soil respiration under nitrogen addition in Alaskan boreal forest, Glob. Change Biol., 14, 1156-1168, 2008.

Berg, B. and Matzner, E.: Effect of $\mathrm{N}$ deposition on decomposition of plant litter and soil organic matter in forest systems, Environ. Rev., 5, 1-25, 1997.

Bobbink, R., Hicks, K., Galloway, J., Spranger, T., Alkemade, R., Ashmore, M., Bustamante, M., Cinderby, S., Davidson, E., Dentener, F., Emmett, B., Erisman, J-W., Fenn, M., Gilliam, F., Nordin, A., Pardo, L., and De Vries, W.: Global assessment of nitrogen deposition effects on terrestrial plant diversity: a synthesis, Ecol. App., 20, 30-59, 2010.

Bond-Lamberty, B. and Thomson, A.: A global database of soil respiration data, Biogeosciences, 7, 1915-1926, doi:10.5194/bg-71915-2010, 2010.

Carpenter, S. R:. Microcosm experiments have limited relevance for community and ecosystem ecology, Ecology, 77, 677-680, 1996.

Carpenter, S. R: The need for large-scale experiments to assess and predict the response of ecosystems to perturbation, in: Successes, limitations and frontiers in ecosystem science, edited by: Pace, M. L. and Groffman, P. M., 287-312, Springer-Verlag, New York, 1998.

Chapin III, F. S.: Nitrogen and phosphorus nutrition and nutrient cycling by evergreen and deciduous understory shrubs in an Alaskan black spruce forest, Can. J. For. Res., 13, 773-781, 1983.

De Vries, W., Reinds, G. J., Gundersen, P., and Sterba, H.: The impact of nitrogen deposition on carbon sequestration in European forests and forest soils. Glob. Change Biol., 12, 1151-1173, 2006.

Eckstein, R. L., Karlsson, P. S., and Weih, M.: Leaf life span and nutrient resorption as determinants of plant nutrient conservation in temperate-arctic regions, New Phyt., 143, 177-189, 1999.
Gamfeldt, L., Snäll, T., Bagchi, R., Jonsson, M., Gustafsson, L., Kjellander, P., Ruiz-Jaen, M. C., Fröberg, M., Stendahl, J., Philipson, C. D., Mikusiński, G., Andersson, E., Westerlund, B., Andrén, H., Moberg, F., Moen, J., and Bengtsson, J.: Higher levels of multiple ecosystem services are found in forests with more tree species, Nature Comm., 4, 1340, doi:10.1038/ncomms2328, 2013.

Gärdenäs, A. I.: Soil respiration fluxes measured along a hydrological gradient in a Norway spruce stand in south Sweden (Skogaby), Plant Soil, 221, 273-280, 2000.

Galloway, J. N., Townsend, A. R., Erisman, J. W., Bekunda, M., Zucong, C., Freney, J. R., Martinelli, L. A., Seitzinger, S. P., and Sutton, M. A.: Transformation of the nitrogen cycle: recent trends, questions, and potential solutions, Science, 320, 889-892, 2008.

Goulden, M. L. and Crill P. M.: Automated measurements of $\mathrm{CO}_{2}$ exchange at the moss surface of a black spruce forest, Tree Phys., 17, 537-542, 1997.

Gower, S. T., Krankina, O., Olson, R. J., Apps, M., Linder, S., and Wang, C.: Net primary production and carbon allocation patterns of boreal forest ecosystems, Ecol. App., 11, 1395-1411, 2001.

Hasselquist, N. J., Metcalfe, D. B., and Högberg, P.: Contrasting effects of low and high nitrogen additions on soil $\mathrm{CO}_{2}$ flux components and ectomycorrhizal fungal sporocarp production in a boreal forest, Glob. Change Biol., 18, 3596-3605, 2012.

Heijmans, M. M. P. D., Arp W. J., and Stuart Chapin III, F.: Carbon dioxide and water vapour exchange from understory species in boreal forest, Agric. For. Met., 123, 135-147, 2004.

Högberg, M. N., Briones, M. J. I., Keel, S. G., Metcalfe, D. B., Campbell, C., Midwood, A. J., Thornton, B., Hurry, V., Linder, S., Näsholm, T., and Högberg, P.: Quantification of effects of season and nitrogen supply on tree below-ground carbon transfer to ectomycorrhizal fungi and other soil organisms in a boreal pine forest, New Phyt., 187, 485-493, 2010.

Hurlbert, S. H: Pseudoreplication and the design of ecological field experiments, Ecol. Mono., 54, 187-211, 1984.

Janssens, I. A., Dieleman, W., Luyssaert, S., Subke, J.-A., Reichstein, M., Ceulemans, R., Ciais, P., Dolman, A. J., Grace, J., Matteucci, G., Papale, D., Piao, S. L., Schulze, E.-D., Tang, J., and Law, B. E.: Reduction of forest soil respiration in response to nitrogen deposition, Nature Geo., 3, 315-322, 2010.

Knorr, M., Frey, S. D., and Curtis, P. S.: Nitrogen additions and litter decomposition: a meta-analysis, Ecology, 86, 3252-3257, 2005.

Kolari, P., Pumpanen, J., Kulmala, L., Ilvesniemi, H., Nikinmaa, E., Grönholm, T., and Hari, P.: Forest floor vegetation plays an important role in photosynthetic production of boreal forests, For. Ecol. Manag., 221, 241-248, 2006.

Lamarque, J.-F., Kiehl, J. T., Brasseur, G. P., Butler, T., CameronSmith, P., Collins, W. D., Collins, W. J., Granier, C., Hauglustaine, D., Hess, P. G., Holland, E. A., Horowitz, L., Lawrence, M. G., McKenna, D., Merilees, P., Prather, M. J., Rasch, P. J., Rotman, D., Shindell, D., and Thornton, P.: Assessing future nitrogen deposition and carbon cycle feedback using a multimodel approach: Analysis of nitrogen deposition, J. Geophys. Res., 110, D19303, doi:10.1029/2005JD005825, 2005.

Lieffers, V. J., Messier, C., Stadt, K. J., Gendron, F., and Comeau, P. G.: Predicting and managing light in the understory of boreal forests, Can. J. For. Res., 29, 796-811, 1999. 
Mencuccini, M. and Grace, J.: Hydraulic conductance, light interception and needle nutrient concentration in Scots pine stands and their relations with net primary productivity, Tree Phys., 16, 459-468, 1996.

Metcalfe, D. B., Fisher, R. A., and Wardle, D. A.: Plant communities as drivers of soil respiration: pathways, mechanisms, and significance for global change, Biogeosciences, 8, 2047-2061, doi:10.5194/bg-8-2047-2011, 2011.

Myneni, R. B., Dong, J., Tucker, C. J., Kaufmann, R. K., Kauppi, P. E., Liski, J., Zhou, L., Alexeyev, V., and Hughes, M. K.: A large carbon sink in the woody biomass of Northern forests, PNASUSA, 98, 14784-14789, 2001.

Nilsson, L. O. and Wallander, H.: Production of external mycelium by ectomycorrhizal fungi in a Norway spruce forest was reduced in response to nitrogen fertilization, New Phyt., 158, 409-416, 2003.

Nilsson, M.-C., and Wardle, D. A.: Understory vegetation as a forest ecosystem driver: evidence from the northern Swedish boreal forest, Front. Ecol. Environ., 3, 421-428, 2005.

Nordin, A., Strengbom, J., Witzell, J., Näsholm, T., and Ericson, L.: Nitrogen deposition and the biodiversity of boreal forests: implications for the nitrogen critical load, Ambio, 34, 20-24, 2005.

Olsson, P., Linder, S., Giesler, R., and Högberg, P.: Fertilization of boreal forest reduces both autotrophic and heterotrophic soil respiration, Glob. Change Biol., 11, 1745-1753, 2005.

Osmond, B., Ananyev, G., Berry, J., Langdon, C., Kolber, Z., Lin, G., Monson, R., Nichol, C., Rascher, U., Schurr, U., Smith, S. and Yakir, D: Changing the way we think about global change research: scaling up in experimental ecosystem science, Glob. Change Biol., 10, 393-407, 2004.

Ostle, N. J., Smith, P., Fisher, R., Ian Woodward, F., Fisher, J. B., Smith, J. U., Galbraith, D., Levy, P., Meir, P., McNamara, N. P., and Bardgett, R. D.: Integrating plant-soil interactions into global carbon cycle models, J. Ecol., 97, 851-863, 2009.

Pan, Y, Birdsey, R. A., Fang, J., Houghton, R., Kauppi, P. E., Kurz, W. A., Phillips, O. L., Shvidenko, A., Lewis, S. L., Canadell, J. G., Ciais, P., Jackson, R. B, Pacala, S. W., McGuire, A. D., Piao S., Rautiainen, A., Sitch, S., and Hayes, D. A.: A large and persistent carbon sink in the world's forests, Science, 333, 988993, 2011

Reay, D. S., Dentener, F., Smith, P., Grace, J., and Feely, R. A.: Global nitrogen deposition and carbon sinks, Nature Geo., 1, 430-437, 2008.

Richardson, A. D., Jenkins, J. P., Braswell, B. H., Hollinger, D. Y., Ollinger, S. V., and Smith, M.-L.:. Use of digital webcam images to track spring green-up in a deciduous broadleaf forest, Oecologia, 152, 323-334, 2007.
Shaver, G., Rastetter, E. B., Salmon, V., Street, L. E., van de Weg, M. J., Rocha, A., van Wijk, M. T., and Williams, M.. Pan-Arctic modeling of net ecosystem exchange of $\mathrm{CO}_{2}$, Phil. Trans. Royal Soc. Lond. B., 368, 1624, doi:10.1098/rstb.2012.048. 2013.

Strengbom, J. and Nordin, A.: Commercial forest fertilization causes long-term residual effects in ground vegetation of boreal forests, For. Ecol. Manag., 256, 2175-2181, 2008.

Strengbom, J., Nordin, A., Näsholm, T., and Ericson, L.: Slow recovery of boreal forest ecosystem following decreased nitrogen input, Funct. Ecol., 15, 451-457, 2001.

Sullivan, T. J: Ecosystem manipulation experimentation as a means of testing a biogeochemical model, Environ. Manage., 21, 15-21, 1997.

Svensson, B. M., Rydin, H., and Carlsson, B. Å.: Clonal plants in the community, in: Vegetation ecology, edited by: Van der Maarel, E. and Bakker, J. P., 129-146, Wiley-Blackwell, Hoboken, 2009.

Tamm, C. O.: Nitrogen in terrestrial ecosystems: questions of productivity, vegetational changes, and ecosystem stability, Springer-Verlag, Berlin, 1991.

Vallack, H. W., Leronni, V., Metcalfe, D. B., Högberg, P., Ineson, P., and Subke, J. A.: Application of nitrogen fertilizer to a boreal pine forest has a negative impact on the respiration of ectomycorrhizal hyphae, Plant Soil, 352, 405-417, 2012.

Vicca, S., Luyssaert, S., Peñuelas, J., Campioli, M., Chapin, F. S., Ciais, P., Heinemeyer, A., Högberg, P., Kutsch, W. L., Law, B. E., Malhi, Y., Papale, D., Piao, S. L., Reichstein, M., Schulze, E. D., and Janssens, I. A.: Fertile forests produce biomass more efficiently, Ecol. Lett., 15, 520-526, 2012.

Vitousek, P. M. and Howarth, R. W.: Nitrogen limitation on land and in the sea: how can it occur?, Biogeochemistry, 13, 87-115, 1991.

Vitousek, P. M., Aber, J. D., Howarth, R. W., Likens, G. E., Matson, P. A., Schindler, D. W., Schlesinger, W. H., and Tilman, D. G.: Human alteration of the global nitrogen cycle: sources and consequences, Ecol. App., 7, 737-750, 1997.

Wardle, D. A., Hörnberg, G., Zackrisson, O., Kalela-Brundin, M., Coomes, D. A.: Long-term effects of wildfire on ecosystem properties across an island area gradient, Science, 300, 972-75, 2003.

Wardle, D. A. and Zackrisson, O.: Effects of species and functional group loss on island ecosystem properties, Nature, 435, 806-810, 2005.

Wardle, D. A., Nilsson, M.-C., Gallet, C., and Zackrisson, O.: An ecosystem-level perspective of allelopathy, Biol. Rev., 73, 305319, 1998.

Whitehead, D. and Gower S. T.: Photosynthesis and light-use efficiency by plants in a Canadian boreal forest ecosystem, Tree Phys., 21, 925-929, 2001. 